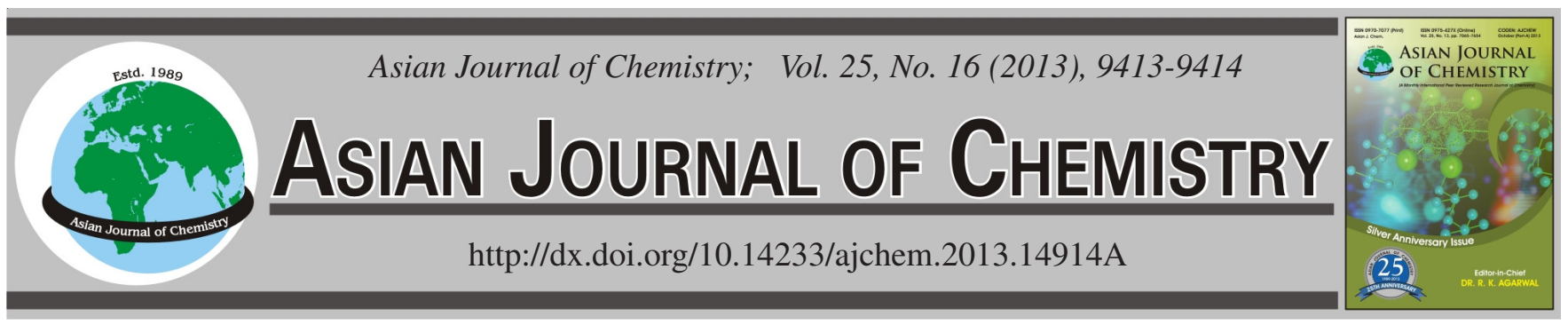

NOTE

\title{
Determination of Heavy Metals and Trace Elements in Selenium-enriched Cherry Fruit by ICP-MS
}

\author{
HongXing ZhanG ${ }^{1, *}$ and YukUI RUI ${ }^{2}$
}

${ }^{1}$ Beijing Key Laboratory of Agricultural Product Safety Detection and Control, Department of Food Science, Beijing University of Agriculture, Beijing 102206, P.R. China

${ }^{2}$ College of Resources and Environmental Sciences, China Agricultural University, Beijing 100193, P.R. China

*Corresponding author: Fax: +86 10 80799170; Tel: +8610 80794124; E-mail: zhanghx511@ gmail.com

(Received: 4 December 2012;

Accepted: 27 September 2013)

AJC-14192

To investigate the food safety and nutritional characteristics of cherry fruits after spraying the Se-enriched foliar fertilizer. Nine kinds of
heavy metals and seven kinds of beneficial trace elements in Se-enriched cherry fruits and normal cherry $\mathrm{CK}$ (not applying $\mathrm{Se}$-enriched foliar
fertilizer) were determined by ICP-MS. The results showed that (1) selenium can reduce the contents of heavy metals $(\mathrm{Pb}, \mathrm{Cu}, \mathrm{Cr}, \mathrm{Ni}, \mathrm{Cd}$ and
$\mathrm{V})$ in fruits of Cherry; (2) selenium-enriched foliar fertilizer can promote the absorption of other trace elements $(\mathrm{K}, \mathrm{Ca}$ and $\mathrm{Fe})$ in addition to
increasing the selenium content in fruit of cherries. So selenium fertilizer can increase nutrition of fruits and reduce the harm of fruits.
Key Words: Se-fertilizer, Heavy metals, Trace elements, Cherry fruit.

Selenium, as one of the essential trace elements, has many important physiological functions on the human body, including antioxidant effects, cardiovascular protection, detoxification, as well as to promote growth and to protect the visual organs and improve immunity role, so selenium-enriched foodstuff is popular ${ }^{1}$. Selenium deficiency can cause a variety of diseases, such as Keshan disease and Kashin-Beck disease; however, if too much intake of selenium will be harm to human body, Seenriched foods must meet the appropriate standards before eating.

More than half of soil in China lacks selenium, so selenium-enriched agricultural products have great market, but selenium-enriched agricultural products is not very standardized. Whether the selenium fertilizer application would affect the food safety or not also require close monitor, especially the change of other harmful ingredients and nutrients in agricultural products after spraying the selenium fertilizer requires further research ${ }^{2}$.

Zhang et $a l .^{3}$ proved that the strawberry had the highest absorption capacity of selenium in the leaf-expansion period and full opening flower period and selenium could slow down the damage of cell membrane integrity by removing malonaldehyde (MDA) accumulation of membrance lipid peroxidation. Further, the toxicity of heavy metals was reduced and the deposition of cadmium and lead in the strawberry leaves and fruits was effectively reduced. This research shows spraying Se-fertilizer to leaves is a sound method for supplementing selenium to the strawberries and suitable amount of selenium can alleviate the toxic to the strawberry caused by heavy metal ${ }^{3}$. But the impact of selenium on absorption of heavy metals in cherries has not been reported.

Selenium was determined by Atomic Fluorescence Spectrometry, the model is AFS-230E produced by Beijing Kechuang Haiguang Instrument Co. Ltd, Beijing of China. This instrument has many advantages of high sensitivity, less interference and wide linear range. The detection limit (DL) is less than $0.09 \mathrm{ng} \mathrm{mL}^{-1}$.

The selenium-enriched cherry was sprayed selenium fertilizer produced by Beijing Sevkon Ecological Science and Technology Limited Company, from the flowering stage, spraying once every 3 weeks. The control is strawberry grown without selenium fertilizer.

Instrument parameters and test procedures referred to Chen's method ${ }^{4}$. Table- 1 shows that the descending order of heavy metals content in cherry is $\mathrm{Pb}>\mathrm{Cu}>\mathrm{Cr}>\mathrm{Ni}>\mathrm{Cd}>$ As $>\mathrm{Co}>\mathrm{V}>\mathrm{Tl}$ and only $\mathrm{Pb}$ is higher $100 \mathrm{ng} \mathrm{mg}^{-1}$, the vast majority elements are lower than $5 \mathrm{ng} \mathrm{mg}^{-1}$.

Compared with normal cherry $(\mathrm{CK})$, the contents of $\mathrm{Pb}$, $\mathrm{Cu}, \mathrm{Cr}, \mathrm{Ni}, \mathrm{Cd}$ and $\mathrm{V}$ in selenium-enriched cherry are significantly lower than those in normal cherry, while Co and As, Tl has no significant difference. 


\begin{tabular}{|c|c|c|}
\hline \multicolumn{3}{|c|}{$\begin{array}{l}\text { TABLE-1 } \\
\text { HEAVY METAL CONTENT OF SELENIUM-ENRICHED } \\
\text { CHERRY AND NORMAL CHERRY }\left(\mathrm{ng} \mathrm{mg}^{-1}, \mathrm{n}=4\right)\end{array}$} \\
\hline Elements & Normal cherry & Se-rich cherry \\
\hline $\mathrm{V}$ & 0.054 & 0.051 \\
\hline $\mathrm{Cr}$ & 3.465 & 3.163 \\
\hline Co & 0.129 & 0.174 \\
\hline $\mathrm{Ni}$ & 2.156 & 1.968 \\
\hline $\mathrm{Cu}$ & 5.559 & 3.053 \\
\hline As & 0.323 & 0.352 \\
\hline $\mathrm{Cd}$ & 0.38 & 0.112 \\
\hline $\mathrm{Tl}$ & 0.004 & 0.003 \\
\hline $\mathrm{Pb}$ & 102.063 & 18.934 \\
\hline
\end{tabular}

Selenium can inhibit the cherry to absorb most of the harmful elements.

Table-2 gives the contents of beneficial elements in normal cherry and selenium-cherry, that the descending order of beneficial elements content in cherry is $\mathrm{K}>\mathrm{Ca}>\mathrm{Fe}>\mathrm{Mn}>$ $\mathrm{Zn}>\mathrm{Se}$.

\section{TABLE-2}

BENEFICIAL ELEMENTS CONTENT OF SELENIUMENRICHED CHERRY AND NORMAL CHERRY $(n=4)$

Elements $\quad$ Normal Cherry $\quad$ Se-rich cherry

$\mathrm{Ca}\left(\mu \mathrm{g} \mathrm{mg}^{-1}\right) \quad 1.172 \quad 1.285$

$\mathrm{Fe}\left(\mu \mathrm{g} \mathrm{mg}^{-1}\right) \quad 0.085 \quad 0.114$

$\mathrm{K}\left(\mu \mathrm{g} \mathrm{mg}^{-1}\right) \quad 14.06 \quad 16.259$

$\begin{array}{lll}\mathrm{Mn}\left(\mu \mathrm{g} \mathrm{mg}^{-1}\right) & 0.025 & 0.025\end{array}$

$\mathrm{Zn}\left(\mu \mathrm{g} \mathrm{mg}^{-1}\right) \quad 0.017 \quad 0.015$

Se $\left(\mathrm{ng} \mathrm{mg}^{-1}\right)$
After applying selenium fertilizers, the contents of $\mathrm{K}, \mathrm{Ca}$, $\mathrm{Fe}$ and $\mathrm{Se}$ in selenium-enriched cherry are significantly higher than those in normal cherry, $\mathrm{Mn}$ and $\mathrm{Zn}$ have no significant difference.

Selenium can promote cherries to absorb beneficial trace elements.

\section{Conclusion}

Selenium can reduce the contents of heavy metals $(\mathrm{Pb}$, $\mathrm{Cu}, \mathrm{Cr}, \mathrm{Ni}, \mathrm{Cd}$ and V) in fruits of cherry. Selenium-enriched foliar fertilizer can promote the absorption of other trace elements ( $\mathrm{K}, \mathrm{Ca}$ and $\mathrm{Fe}$ ) in addition to increasing the selenium content in fruit of cherries.

\section{ACKNOWLEDGEMENTS}

This work was supported by the Key National Natural Science Foundation of China (No. 41130526).

\section{REFERENCES}

1. G.S. Bañuelos, S.C. Fakra, S.S. Walse, M.A. Marcus, S.I. Yang, I.J. Pickering, E.A. Pilon-Smits and J.L. Freeman, Plant Physiol., 155, 315 (2011)

2. L.-H. Li, Q.-L. Lin and H.-J. Chen, Modern Food Sci. Technol., 21, 198 (2005).

3. H.-Y. Zhang, T. Han, L. Tian and Y.-N. Wang, Acta Horticult. Sin., 38, 409 (2011).

4. J.X. Chen, Fujian Anal. Testing, 21, 46 (2012). 